\title{
ЗМІСТ ПРОФЕСІЙНОЇ ПІДГОТОВКИ МАЙБУТНІХ ФАХІВЦІВ ІЗ ФІЗИЧНОї ТЕРАПІї У ВЕЛИКІЙ БРИТАНІї
}

\author{
Юлія Копочинська ${ }^{1}$ \\ ${ }^{1}$ Міжнародний науково-технічний університет імені акад. Ю. Бугая, Київ, Україна, уouliaco@ukr.net \\ https://doi.org/10.29038/2220-7481-2020-01-21-28
}

\begin{abstract}
Анотації
Актуальність теми дослідження. Створення необхідного освітнього досвіду та досвіду підготовки майбутніх фахівців із фізичної терапії до майбутньої професійної діяльності у Великобританії свідчить про необхідність вищої освіти та обов'язкового практичного навчання. Мета та методи дослідження. Мета дослідження - представити результати наукового педагогічного дослідження змісту професійної підготовки майбутніх фахівців із фізичної терапії в закладах вищої освіти Великобританії. Для досягнення мети дослідження використано комплекс взаємопов'язаних методів дослідження, а саме: бібліографічний аналіз, порівняння та узагальнення для виявлення особливостей професійної підготовки фахівців із фізичної терапії у Великій Британії; структурно-функціональний аналіз; інтерпретаційно-аналітичний. Результати роботи. Розглянуто зміст навчальних дисциплін у вищих навчальних закладах Великобританії, де існує трирічна програма професійної підготовки фізичних терапевтів за рівнем бакалавра. Установлено, що навчальний курс орієнтований на функціональні системи людського організму та вивчає їх вплив на здатність організму рухатися й ефективно функціонувати. В університеті студенти співпрацюють зі студентами інших спеціальностей. За результатами аналізу навчальних програм професійної підготовки фізичних терапевтів за освітнім рівнем бакалавра можна констатувати, що навчальний процес орієнтований, насамперед, на роботу з людьми задля максимізації їхніх функціональних можливостей та їхнього потенціалу. Висновки. Особливістю практичного навчання майбутніх фахівців із фізичної терапії $€$ навчання студентів через безпосередній контакт із пацієнтами, а також через досвід подолання широкого спектра медичних проблем на різних базах практики. Курс зосереджений на функціональних системах людського організму й вивчає, як вони впливають на здатність організму рухатися та ефективно функціонувати. Університети Великобританії підтримують інноваційні підходи до розробки програм практичної професійної підготовки та їх упровадження в навчальний процес, а характер навчання в рамках окремих програм залежить від старатегії професійної підготовки майбутніх фахівців із фізичної терапії самих університетів.
\end{abstract}

Ключові слова: професійна підготовка, майбутній фахівець із фізичної терапії, закордонний досвід професійної підготовки, зміст навчальних програм, фізична терапія, професійне навчання фізичних терапевтів.

Юлия Копочинська. Содержание профессиональной подготовки будущих специалистов по физической терапии в Великобритании. Актуальность темы исследования. Создание необходимого образовательного опыта и опыта подготовки будущих специалистов по физической терапии к будущей профессиональной деятельности в Великобритании свидетельствует о необходимости высшего образования и обязательного практического обучения. Цель и методы исследования. Цель исследования - представить результаты научного педагогического исследования содержания профессиональной подготовки будущих специалистов по физической терапии в учреждениях высшего образования Великобритании. Для достижения цели исследования использован комплекс взаимосвязанных методов исследования, а именно: библиографический анализ, сравнение и обобщение для выявления особенностей профессиональной подготовки специалистов по физической терапии в Великобритании; структурно-функциональный анализ; интерпретационно-аналитический. Результаты работы. Рассматривается содержание учебных дисциплин в высших учебных заведениях Великобритании, где трехлетняя программа профессиональной подготовки физических терапевтов по уровню бакалавра. Установлено, что учебный курс ориентирован на функциональные системы человеческого организма и изучает их влияние на способность организма двигаться и эффективно функционировать. В университете студенты сотрудничают со студентами других специальностей. По результатам анализа учебных программ профессиональной подготовки физических терапевтов по образовательному уровню бакалавра можно констатировать, что учебный процесс ориентирован прежде всего на работу с людьми с целью максимизации их функциональных возможностей и их потенциала. Bbыводы. Особенностью практического обучения будущих специалистов по физической терапии является обучение студентов через непосредственный контакт с пациентами, а также через опыт преодоления широкого спектра медицинских проблем на различных базах практики. Курс сосредоточен на функциональных системах человеческого организма и изучает, как они влияют на способность организма двигаться и эффективно функционировать. Университеты Великобритании поддерживают инновационные подходы к разработке программ практической профессиональной подготовки и их внедрение в учебный процесс, а характер обучения в рамках 
отдельных программ зависит от старатегии профессиональной подготовки будущих специалистов по физической терапии самих университетов.

Ключевые слова: профессиональная подготовка, будущий специалист по физической терапии, зарубежный опыт профессиональной подготовки, содержание учебных программ, физическая терапия, профессиональное обучение физических терапевтов.

Yuliia Kopochynska. Contents of Professional Training of Future Physical Therapy Specialists in the United Kingdom. Relevance of the Research Topic. Creating the necessary educational experience and the experience of preparing future Physical Therapy professionals for future professional activity in the United Kingdom demonstrates the need for higher education and compulsory practical training. Purpose and Methods of the Research. The purpose of the study is to present the results of a scientific pedagogical study of the content of professional training of future Physical Therapy Specialists in the United Kingdom higher education institutions. To achieve the goal of the study, a set of interrelated research methods was used, namely: bibliographic analysis, comparisons and generalizations to identify the peculiarities of the training of Physical Therapy professionals in the United Kingdom; structural and functional analysis; interpretative-analytical. Results of the Research. The content of the educational disciplines in higher educational establishments of the United Kingdom, where the three-year program of professional training of Physical Therapists of Bachelor level, is considered. It is established that the training course is focused on the functional systems of the human body and examines their influence on the body's ability to move and function effectively. At the University, students collaborate with students of other specialties. According to the analysis of the training programs of vocational training of physical therapists by the educational level of the Bachelor, it can be stated that the educational process is focused primarily on working with people in order to maximize their functional capabilities and their potential. Key Findings. The feature of practical training of future Physical Therapy Specialists is to educate students through direct contact with patients, as well as through the experience of overcoming a wide range of medical problems at different bases of practice. The course focuses on the functional systems of the human body and examines how they affect the body's ability to move and function effectively. The universities of the United Kingdom support innovative approaches to the development of practical training programs and their implementation in the educational process, and the nature of the training within individual programs depends on the strategic training of future specialists in Physical Therapy of the universities themselves.

Key words: vocational training, future Physical Therapy Specialist, foreign experience of vocational training, content of training programs, Physical Therapy, professional training of Physical Therapists.

Вступ. Сьогодні система вищої освіти фахівців із фізичної терапії має завдання - навчити студентів самостійної практики в галузі фізичної терапії, ужити рішучих дій у професійних ситуаціях, тобто стимулювати професійне мислення, активізувати творчий потенціал, розвивати сильний інтерес до освіти, формувати професійну ідентичність майбутніх фахівців.

Створення потрібного освітнього досвіду та досвіду підготовки майбутніх фахівців із фізичної терапії до майбутньої професійної діяльності у Великобританії свідчить про необхідність вищої освіти та обов'язкового практичного навчання. Ураховуючи специфіку цієї професії, значну увагу приділяємо формуванню професійної самосвідомості, самобутності та професіоналізму через практичне навчання $[4$, с. 153$]$.

У статутному товаристві фізіотерапії зазначено, що навчання на основі практики $є$ важливою й невід'ємною частиною навчального процесу та життєво важливим для навчального й професійного розвитку студентів. Департамент охорони здоров’я визнає, що практичний досвід студентів - це найважливіший спосіб підготувати їх до подолання майбутніх перешкод у будь-яких умовах професійної діяльності [4, с. 156].

Ми вважаємо, що вивчення особливостей підготовки майбутніх фахівців із фізичної терапії у Великобританії є вагомим внеском у модернізацію та підвищення якості підготовки майбутніх фахівців із фізичної терапії у вітчизняних закладах вищої освіти.

Мета дослідження - представити результати наукового педагогічного дослідження змісту професійної підготовки майбутніх фахівців із фізичної терапії в закладах вищої освіти Великобританії.

Матеріали й методи дослідження. Для досягнення поставленої мети використано комплекс взаємопов'язаних методів дослідження, а саме: теоретичні - бібліографічний аналіз, порівняння та узагальнення для виявлення особливостей професійної підготовки фахівців із фізичної терапії у Великій Британії; структурно-функціональний аналіз - для обгрунтування дидактичних засад професійної підготовки фахівців із фізичної терапії; інтерпретаційно-аналітичний - для проведення аналізу літературних, документальних й інших джерел, зокрема англомовних, із використанням інтерпретації, систематизації, порівняння та узагальнення; пошуковий - для формування узагальнених 
висновків, виявлення раціонального й практично-ціннісного у наукових розробках із порівняльної педагогіки.

Результати дослідження. У закладах вищої освіти Великої Британії трирічна програма професійної підготовки фізичних терапевтів за освітнім рівнем бакалавра орієнтована на роботу з людьми для максимізації їхніх функціональних можливостей та їхнього потенціалу.

Навчальний курс зосереджений на функціональних системах організму людини й вивчає їх вплив на здатність організму ефективно рухатися та функціонувати. Основні сфери включають нервовом'язову, опорно-рухову, серцево-судинну й респіраторну терапію в умовах як гострої, так і хронічної стадії перебігу захворювання. В університеті студенти під час навчання співпрацюють зі студентами 3 інших, суміжних із фізичною терапією спеціальностей. Саме міжпрофесійна робота в команді стане центральним елементом майбутньої кар'єри студентів [9].

Щойно студенти отримали знання про клінічні науки, які покладено в основу функцій і дисфункцій людського організму, вони починають навчання на практиці, яке зосереджене на конкретних потребах кожного пацієнта/клієнта чи групи пацієнтів/клієнтів. Так, студенти стають експертами в розумінні конкретних психологічних, культурних й соціальних факторів у контексті догляду, а також дізнаються про належне врахування потреб і здібностей інших членів мультидисциплінарної команди, уключаючи опікунів й інших працівників охорони здоров'я та соціального обслуговування [3].

Структура навчального курсу в університетах свідчить, що фахова освіта фізичних терапевтів сильна як у теорії, так і в практиці. Кожен із трьох років студенти зобов'язані виконувати обов'язкові модулі, які залежать від ваги кредиту, а також два місяці практики. Для того щоб перейти на наступний рік навчання, студентам потрібно задовільно скласти кожен із модулів [2, с. 179]. Тоді студент має право складати вступні сесії на початку кожного навчального року, щоб підтримати свій перехід між академічними рівнями.

На першому курсі студенти вивчають п'ять обов'язкових модулів, уключаючи «Основи професійної практики» (Foundations of professional practice), «Науки про людину» (Human Sciences), «Теорія і практика фізичної терапії 1» (Physiotherapy theory and practice 1), «Інтерпрофесійне навчання рівень 1» (Interprofessional learning - Level 1), «Обов’язкове навчання 1» (Mandatory training 1) та «Навчальна практика 1» (Practice education 1).

«Основи професійної практики (Foundations of professional practice)»- це мультидисциплінарний модуль першого року з ерготерапії, фізіотерапії й мовної терапії. Він стосується низки стандартів кваліфікації, які є загальними для кожної з цих професій. Цей модуль готує студентів до роботи у сфері охорони здоров'я й соціального захисту. Студенти дізнаються про різноманітність контекстів, у яких надаються послуги, у тому числі громадське здоров'я й зміцнення здоров'я.

Модуль «Науки про людину (Human Sciences)» націлений на ознайомлення студентів із фундаментальними теоретичними основами клінічних наук, необхідних для практиктичної діяльності. Вивчаються біопсихосоціальні процеси, що покладені в основу функціонування людського організму. Основну увагу приділено розумінню основних анатомічних, фізіологічних, психологічних і соціологічних процесів, що перебувають в основі життя людини. Результати навчання слугуватимуть основою для модулів професійної практики у сфері ерготерапії й фізіотерапії.

У модулі «нтерпрофесійне навчання - рівень 1 (Interprofessional learning - Level 1)» студенти співпрацюють з іншими представниками програм охорони здоров'я в університеті на двогодинному навчальному заході.

Модуль «Обов'язкове навчання 1 (Mandatory training 1)» призначений для студентів, котрі займаються ерготерапією, фізіотерапією й мовною терапією, котрі повинні пройти частину клінічної практики в рамках свого ступеня. Обов'язкове навчання 1 (Mandatory training 1)» $є$ обов'язковою умовою цих програм. Важливо, щоб учні провели низку навчальних занять, щоб забезпечити власну безпеку й безпеку користувачів послуг, персоналу та всіх, із ким вони співпрацюють.

Модуль «Теорія та практика фізичної терапії 1 (Physiotherapy theory and practice 1)» стосується розв'язання проблем і клінічних міркувань, а також, де це можливо, координується з викладанням анатомічних сфер нижніх і верхніх кінцівок і гуманітарними науками. Перед цим уводиться анатомія хребта. В останні тижні вводиться навчання на основі запитів із застосуванням тематичних досліджень. Подальші заняття в рамках модуля «Навчальна практика 1 (Practice education 1)» дають змогу студентам продовжити клінічне застосування та придбання практичних навичок.

«Навчальна практика 1 (Practice education 1)» знайомить студентів із базовими навичками, потрібними для того, щоб стати фахівцем у сфері охорони здоров'я й соціального захисту з навчанням, 
заснованим на індивідуальних і міждисциплінарних навичках, у поєднанні з практичними заняттями. Студенти випробовують поточну практику у сфері ерготерапії й фізіотерапії. Акцентовано на ознайомленні студентів з основними клінічними навичками в рамках міжпрофесійного навчання. Протягом усього модуля студенти вивчають ранні атрибути працевлаштування та починають розробляти свій портфель програм підвищення працездатності пацієнтів. На цьому етапі вводитиметься контент для працевлаштування.

На другому курсі обов'язкові модулі включають «Практику на основі досвіду (Evidence based practice)», «Обов’ язкове навчання 2 (Mandatory training 1)», «Теорію та практику фізичної терапії 2 (Physiotherapy theory and practice 2)», «Навчальну практику 2 (Practice education 2)».

Модуль «Практика на основі досвіду (Evidence based practice)» грунтується на вступних елементах дослідження, висвітлених на першому році професійної підготовки в рамках модуля «Основи професійної практики (Foundations of professional practice)». Використовуючи педагогічні підходи, засновані на змішаному навчанні, дослідницький компонент запровадить якісні й кількісні методології, використовуючи досвід діяльності для формування базового розуміння первинних досліджень і розуміння критичних навичок оцінювання.

Модуль «Обов'язкове навчання 2 (Mandatory training 1)» розроблений для ерготерапевтів, фізіотерапевтів та мовних терапевтів, які зобов'язані пройти години клінічної практики в рамках свого освітнього ступеня. Важливим $€$ те, щоб студенти провели низку навчальних занять для набуття досвіду із забезпечення власної безпеки та безпеки пацієнтів/клієнтів і персоналу.

Модуль «Теорія та практика фізичної терапії 2 (Physiotherapy theory and practice 2)» об'єднує теорію й практику задля розвитку навичок студента в низці фізіотерапевтичних утручань, які відновлюють функціональний стан і рух людини протягом життя. Модуль спирається на основі знань та навичок, отриманих у першому навчальному році, і використовує, заснований на доказах підхід до клінічного обгрунтування й розв'язання проблем. Студенти вчаться адаптувати та модифікувати процес фізіотерапевтичного втручання й оцінки залежно від потреб пацієнта/клієнта. Студентам потрібно інтегрувати та застосовувати гуманітарні науки, щоб продемонструвати своє клінічне мислення 3 посиланням на структуру Міжнародної класифікації функціонування, обмежень життєдіяльності та здоров'я (МКФ). Увагу також приділяють ознайомленню студентів із тим, яка роль фізіотерапевта в системі охорони здоров'я. Студенти починають розглядати питання про профілактику захворювань і підвищення особистого й суспільного благополуччя. Навчання відбувається за допомогою освіти на основі запитів (enquiry-based learning (EBL)), за яким студенти досліджують функції та рухи людини й вплив дисфункції систем організму на них. Навчання на основі запитів розвивається за своєю складністю та комплексним підходом до управління. Студентам буде запропоновано замислитися про свою сферу практики й почати думати про себе як про «агентів змін», що працюють у складі мультидисциплінарної команди.

Модуль «Навчальна практика 2 (Practice education 2)» заснований на модулі «Навчальна практика 1 (Practice education 1)». Викладання здійснюється на основі міждисциплінарних навичок поряд із практичними заняттями студентів. Міждисциплінарний зміст уключає в себе написання змісту й управління інформацією, стійкість і вивчення ролі фізіотерапевта в командах та чітке розуміння теорії й практики наставництва.

На третьому курсі студенти проходять «Контекст практики (Context of practice)», «Фізіотерапевтична практика (Physiotherapy practice)», «Додаткова освіта (Placement education)», «Професійний розвиток (Professional development)».

Модуль «Контекст практики (Context of practice)» спрямований на підготовку студентів до поточних питань обслуговування, які вплинуть на їхню майбутню професійну діяльність. Навчальна програма грунтується на знаннях студентів політики охорони здоров'я, отриманих на практиці й в інших частинах курсу, що дає можливість проаналізувати, як розвиваються урядові ініціативи, політика охорони здоров'я, питання участі пацієнтів та громадськості, клінічне керівництво, поліпшення обслуговування, придатність для практики і якісне надання послуг під час роботи у відповідних установах або в соціальних службах. Цей модуль також охоплює більш широкий контекст практики, розглядаючи внесок інших фахівців, пацієнтів й осіб, які здійснюють догляд, надання медичної та соціальної допомоги. Він призначений для того, щоб зосередити увагу на поточних проблемах і практиці надання медичних та соціальних послуг. Заняття проводяться протягом цілих днів викладання й навчання, кожне з яких фокусується на певній темі, що має безпосередній зв'язок із наданням якісних послуг. Усі семінари протягом тематичних днів використовують завдання щодо поліпшення сервісу. До 
переліку тем уключені такі теми, як «Вступ в поліпшення якості та обслуговування», «Якості фізичного терапевта», «Розробка бізнес-кейсів», «Управління змінами», «Якість послуг», «Вимірювання якості послуг», «Залучення користувачів послуг, «Практичні питання».

Модуль «Фізіотерапевтична практика 3 (Physiotherapy practice 3)»готує майбутніх фахівців із фізіотерапії до того, щоб стати впевненим і компетентним фізіотерапевтами. Студенти далі розвивають своє розуміння нюансів фізіотерапевтичних утручань, питань поєднання теорії та практики поряд з усе більш складними навичками клінічного мислення. Це сприяє навчанню студентів навичок розв'язання проблем, клінічного мислення й прийняття рішень на основі фактичних даних на практики. У цьому модулі студенти працюють разом зі студентами з курсу ерготерапії під час загальних тем (суспільна охорона здоров'я, старіння та практичні навички).

Модуль «Додаткова освіта (Placement education)» заснований на модулі «Навчальна практика 2 (Practice education 2)» із викладанням на основі індивідуальних і міждисциплінарних навичок поряд із практичними заняттями студентів. Відбувається перехід студента до компетентної й автономної практичної діяльності. Студенти проходять шеститижневе навчання, що закінчується перехідним періодом, який організовується студентом з урахуванням його бажаної сфери практики. Факультатив дає можливість застосувати основні навички та знання, отримані протягом усієї програми. У рамках модуля учні спираються на свої знання, клінічні навички та професійний розвиток, що свідчить про здатність брати участь в оцінці й утручання на різних рівнях складності. Це сприяє тому, що студент просуватиме й активно застосовуватиме вже набуті навички управління, догляду та наставництва. Студенти готуються до практики за допомогою серії прогресивних лекцій і семінарів. Навчання орієнтоване на інтеграцію освіти з попередніх навчальних модулів і просування до стандартів нового кваліфікованого фахівця з фізіотерапії. Студенти проводять підготовчі заняття за власним вибором, а також пленарні засідання, щоб планувати розвиток практики. Результати навчання 3 цього модуля мають прогресивний характер й оцінюються 3 використанням формальних критеріїв оцінки, уключаючи безпеку практики, професіоналізм, клінічне мислення, навички міжособистісного спілкування, керівництво пацієнтами/клієнтами, управління інформацією, а також особистісний та професійний розвиток.

Модуль «Професійний розвиток (Professional development)» завершує тему професійної підготовки фахівців із фізіотерапії освітнього рівня бакалавра, яка триває протягом трьох навчальних років. Він допомагає студенту завершити дипломну роботу, розпочату на другому році навчання, яка оцінює навички дослідження за допомогою структурованого огляду літератури. Він також готує студентів до практики за темами, що стосуються переходу від учня до практика. Студентів навчають виявляти й реагувати на зміни у сфері охорони здоров'я та соціальної допомоги, а також проявляти новаторство й рішучість у використанні наукових даних для підтримки професійної діяльності.

Великого значення в університетах Великої Британії надають підготовці студентів до перебування на базах практик. Навчальний план рекомендує встановлювати обопільні взаємини між клініками й університетами та вимагає тісно пов'язувати теорію з практикою. Існує певна відмінність у способах підготовки студентів, починаючи від викладання спеціальних загальноприйнятих тем до індивідуальних курсів за темами, такими як здоров'я й безпека чи СЛР (серцево-легенева реанімація). Більшість підготовчої діяльності проводиться в суто професійному напрямі. Серед форм навчання - лекції, семінари, симпозіуми, індивідуальні консультації та інформаційні пакети. Деякі заняття виходять за рамки навчальних тем, інші чітко дотримуються професійного напряму. Тривалість підготовчої практики до діяльності відрізняється від загальних консультацій до 3-х тижневих ознайомчих програм i факультативних програм за власним вибором студентів. Організаційні питання щодо ознайомчих заходів повністю перебувають на відповідальності викладача практики [10].

Навчання на місцях практичного засвоєння матеріалу робить значний внесок в освіту й професійний розвиток студентів. Перебуваючи на місці практичного навчання, студент-фізичний реабілітолог працює під прямим контролем викладача практики, який здійснює нагляд, допомагає в навчанні та оцінює компетентність студента. В університетах Великої Британії використовуються різні моделі нагляду за діяльністю студентів під час практики. Викладачі-практики можуть контролювати одного (1:1) чи більше ніж одного (2/3/4:1) студента в межах однієї бази. За останні десять років домінувала модель $1: 1$, але нещодавно почали експериментувати 3 моделями, у яких один викладач здійснює нагляд за більшою кількістю студентів, а саме: $2: 1,3: 1,4: 1,3: 2$, та використовувати командні моделі. South East London Education Consortium та South Essex Education and Training Purchasing Consortium схвалили й фінансували моделі нагляду трьох видів: модель 2:1; модель нагляду за 
студентами, котрі перебувають на різних базах практик (роз’єднане місце розташування) та командну модель. Університети підтримують модель 2:1 як протидію нестачі баз практик. Найсильніший теоретичний аргумент на користь моделі 2:1 - це можливість двом студентам бути залученими в спільний процес навчання, який виявився досить ефективним у великій різноманітності ситуацій, уключаючи місце розміщення на базі клініки [4, С.154].

Університетами Великої Британії дуже активно підтримуються іноваційні підходи до розробки програм практичного професійного навчання та введення їх у процес навчання, а характер навчання в рамках індивідуальних програм залежить від самих університетів. Навчання в університеті та навчання на базах практик засновано на принципі гармонійного взаємозалежного поєднання теорії й практики [7, с. 821]. І викладачі університету, і викладачі баз практик, а також їхні помічники, залучені в процес навчання студентів, одностайно та чітко розуміють ролі й обов'язки майбутнього кваліфікованого фізичного реабілітолога. Існує тісний взаємозв'язок між університетами й базами практик, а роль викладача на базі практики $є$ ключовою в досягненні навчальних цілей. Плавний перехід від «наглядача» до «викладача» практичного професійного навчання та здатність бути делікатним зі студентами в питаннях культурного й етнічного походження $\epsilon$ прикладами, що характеризують справжнього клінічного викладача. Так, на основі навчальних планів університетів Великої Британії, створено стандарти відповідності клінічного викладача в навчанні на практичній основі. Особливістю практичного навчання майбутніх фахівців із фізичної реабілітації $\epsilon$ навчання студентів через безпосередній контакт із пацієнтами, а також через досвід подолання широкого спектра медичних проблем на різних базах практики. Зазначимо, що навчання майбутніх фізичних реабілітологів $\epsilon$ основним обов'язком кваліфікованих фізичних реабілітологів із метою забезпечення появи наступного покоління професіоналів, практично компетентних у професійних питаннях [4, с. 157].

Дискусія. Питання про професійне навчання майбутніх фахівців із фізичної терапії досліджували С. В. Гук [4], Л. Сущенко та О. Базильчук [11, с. 14]. Дослідники наголосшували, що вивчення зарубіжного досвіду підготовки фахівців, його інтеграція в національну освітню сферу є необхідною умовою для вдосконалення вітчизняної системи професійного навчання майбутніх фахівців із фізичної терапії.

С. В. Гук запевняє, що питання вдосконалення змісту професійної підготовки майбутніх фахівців із фізичної терапії залишається відкритим [4, с. 157]. Комплексних досліджень щодо того, як слід здійснювати професійне навчання спеціалістів із фізичної терапії з урахуванням затребуваної науково обгрунтованої організації навчального процесу й майстерності передових країн і регіональних особливостей України, ще не проведено, що підтверджує доцільність обговорення цього питання в різних значеннях.

Як один зі способів розв'язання проблем, зокрема підвищення якості професійної підготовки фахівців із фізичної терапії, ми пропонуємо дослідження зарубіжного досвіду підготовки фахівців у цій галузі [1, с. 116].

За даними аналізу публікацій зарубіжних дослідників установлено, що схема побудови навчальної програми в освітянській організації не тотожна виведенню $з$ навчальної програми: це скоріше деривація організації змісту й практики студентів, а також спосіб прояву професійних та соціальних компетенцій, необхідних випускнику $[12$, с. 5]. Однією 3 важливих переваг такої організації навчання, на думку зарубіжних науковців, $є$ те, що розміщення навчальних дисциплін у змістовному навчальному шляху для студентів створює альтернативу традиційній схемі, у якій принципу організації дисциплін за циклами та блоками не має бути математично тематичним, але багато в чому суто похідним і досить абстрактним та, головне, непрозорим для учня й навіть учителя як реальних предметів навчальної програми [6, с. 11]. Модуль дає змогу студенту бачити, які закони поєднують дисципліни, й обирати склад своєї професійної освіти вільно та свідомо. Усе це створює умови для формування гнучкої індивідуалізованої деривації освіти [13, с. 370].

Висновки. За результатами аналізу навчальних програм професійної підготовки фізичних терапевтів за освітнім рівнем бакалавра можна стверджувати, що навчальний процес орієнтований, передусім, на роботу з людьми для максимізації їхніх функціональних можливостей та потенціалу.

Навчальний курс зосереджений на функціональних системах організму людини й вивчає, як вони впливають на здатність організму ефективно рухатися та функціонувати. Основні сфери включають нервову, м'язову, опорну, рухову, серцево-судинну та респіраторну терапію в умовах як гострої, так і хронічної стадії перебігу захворювання. 
Університетами Великої Британії дуже активно підтримуються інноваційні підходи до розробки програм практичного професійного навчання та уведення їх у процес навчання, а характер навчання в рамках індивідуальних програм залежить від самих університетів. Навчання в університеті та навчання на базах практик засновано на принципі гармонійного взаємозалежного поєднання теорії й практики.

В університетах простежуємо міждисциплінарний етос. Це означає, що студенти під час навчання співпрацюватимуть зі студентами з інших, суміжних із фізичною терапією, спеціальностей. На нашу думку, це $є$ важливим елементом формування професійної ідентичності студентів, оскільки саме міжпрофесійна робота в команді стане центральним елементом майбутньої кар'єри студентів.

Перспективним питанням для подальших досліджень $є$ більш детальне вивчення особливостей організації практичної підготовки та міжпрофесійної освіти майбутніх фахівців із фізичної терапії в закладах вищої освіти Великої Британії.

\section{Джерела та література}

1. Atkinson R., McElroy T. Preparedness for physiotherapy in private practice: Novices identify key factors in an interpretive description study. Manual Therapy. 2016. № 22. P. 116-121. URL: https://doi.org/10.1016/j.math. 2015.10.016

2. Becker M., Dudley-Javoroski S., Shields R. K. Professionalism Values in Health Science Education: Self- and Peer-Assessment of Faculty, Staff, and Students. Journal of Allied Health. 2017. № 46(3). P. 178-184.

3. BSc Physiotherapy. URL: https://www2.uea.ac.uk/study/undergraduate/degree/detail/bscphysiotherapy?_ga= 2.183960741.2020174664.1564812811379396234.1564812811 (date of appeal 27.02.2020).

4. Guk S. V. Features of the practical training of specialists in physical rehabilitation in the United Kingdom. Modern information technologies and innovative teaching methods in the training of specialists: methodology, theory, experience, problems. 2014. № 38. P. 152-157. URL: http://nbuv.gov.ua/UJRN/Sitimn_2014_38_33 (date of appeal 27.02.2020).

5. Hammond R., Cross V., Moore A. The construction of professional identity by physiotherapists: A qualitative study. Physiotherapy. 2016. № 102, P. 71-77, https://doi.org/10.1016/j.physio.2015.04.002

6. Harman K., Sim M., LeBrun J., Almost J., Andrews C., Davies H., Khalili H., Sutton E., Price, S. Physiotherapy: an active, transformational, and authentic career choice. Physiotherapy Theory and Practice. 2019. P. 1-14. URL: https://doi.org/10.1080/09593985.2019.1639230.

7. Korpi H., Piirainen A., Peltokallio L. Practical work in physiotherapy students' professional development. Reflective Practice. 2017. P. 821-836. https://doi.org/10.1080/14623943.2017.1361920

8. Lee S., Denniston C., Edouard V., Palermo C., Pope K., Sutton K., Waller S.,Ward B., Rees C. Supervision training interventions in the health and human services: realist synthesis protocol. British Medical Journal, 2019. Open. 9. e025777. https://doi.org/10.1136/bmjopen-2018-025777.

9. Physiotherapy Courses in UK. URL: https://www.studying-in-uk.org/physiotherapy-courses-in-uk/ (date of appeal 27.02.2020).

10. School of Health Professions. BSc «Hons» Physiotherapy. URL: https://www.plymouth.ac.uk/courses/undergraduate/bsc-physiotherapy (date of appeal 27.02.2020).

11. Sushchenko, L., Bazylchuk, O. Comparative Analysis of Professional Training of Future Specialists in Physical Therapy in Higher Educational Establishments of Ukraine and Europe. Comparative Professional Pedagogy. 2018. № 8(1), P. 13-19. https://doi.org/10.2478/rpp-2018-0002

12. Takashima R., Saeki K. Practical Actions Shaped by the Internal Structures of Occupational Therapists Professional Identities. The Open Journal of Occupational Therapy. 2019. № 7. P. 1-16. https://doi.org/ 10.15453/2168-6408.1567.

13. Tynjala P., Virtanen A., Klemola U., Kostiainen,E., Rasku-Puttonen H. Developing social competence and other generic skills in teacher education: Applying the model of integrative pedagogy. European Journal of Teacher Education. 2016. № 39, P. 368-387. https://doi.org/10.1080/02619768.2016.1171314

14. Ziebart C., MacDermid J. C. Reflective Practice in Physical Therapy: A Scoping Review. Physical Therapy. 2019. № 99(8), P. 1056-1068.

\section{References}

1. Atkinson, R., McElroy, T. (2016). Preparedness for physiotherapy in private practice: Novices identify key factors in an interpretive description study. Manual Therapy, 22, 116-121. https://doi.org/10.1016/j.math. 2015.10.016

2. Becker, M., Dudley-Javoroski, S., Shields, R. K. (2017). Professionalism Values in Health Science Education: Self- and Peer-Assessment of Faculty, Staff, and Students. Journal of Allied Health, 46(3), 178-184.

3. BSc Physiotherapy. Retrieved 27.02.2020 from: https://www2.uea.ac.uk/study/undergraduate/degree/detail/ bscphysiotherapy?_ga=2.183960741.2020174664.1564812811379396234.1564812811

4. Guk, S. V. (2014). Features of the practical training of specialists in physical rehabilitation in the United Kingdom. Modern information technologies and innovative teaching methods in the training of specialists: 
methodology, theory, experience, problems, 38, 152-157. Retrieved 27.02.2020 from: http://nbuv.gov.ua/UJRN/ Sitimn_2014_38_33 (in Ukrainian).

5. Hammond, R., Cross, V., Moore, A. (2016). The construction of professional identity by physiotherapists: $A$ qualitative study. Physiotherapy, 102, 71-77. https://doi.org/10.1016/j.physio.2015.04.002

6. Harman, K., Sim, M., LeBrun, J., Almost, J., Andrews, C., Davies, H., Khalili, H., Sutton, E., Price, S. (2019). Physiotherapy: an active, transformational, and authentic career choice. Physiotherapy Theory and Practice, 1-14. https://doi.org/10.1080/09593985.2019.1639230.

7. Korpi, H., Piirainen, A., Peltokallio, L. (2017). Practical work in physiotherapy students' professional development. Reflective Practice, 821-836. https://doi.org/10.1080/14623943.2017.1361920

8. Lee, S., Denniston, C., Edouard, V., Palermo, C., Pope, K., Sutton, K., Waller, S.,Ward, B., Rees, C. (2019). Supervision training interventions in the health and human services: realist synthesis protocol. British Medical Journal, Open. 9. e025777. https://doi.org/10.1136/bmjopen-2018-025777.

9. Physiotherapy Courses in UK. Retrieved 27.02.2020 from: https://www.studying-in-uk.org/physiotherapycourses-in-uk/

10. School of Health Professions. BSc «Hons» Physiotherapy. Retrieved 27.02.2020 from: https://www.plymouth. ac.uk/courses/undergraduate/bsc-physiotherapy

11. Sushchenko, L., Bazylchuk, O. (2018). Comparative Analysis of Professional Training of Future Specialists in Physical Therapy in Higher Educational Establishments of Ukraine and Europe. Comparative Professional Pedagogy, 8(1), 13-19. https://doi.org/10.2478/rpp-2018-0002

12. Takashima, R., Saeki, K. (2019). Practical Actions Shaped by the Internal Structures of Occupational Therapists Professional Identities. The Open Journal of Occupational Therapy, 7, 1-16. https://doi.org/10.15453/21686408.1567.

13. Tynjala, P., Virtanen, A., Klemola, U., Kostiainen, E., Rasku-Puttonen, H., (2016). Developing social competence and other generic skills in teacher education: Applying the model of integrative pedagogy. European Journal of Teacher Education, 39, 368-387. https://doi.org/10.1080/02619768.2016.1171314

14. Ziebart, C., MacDermid, J. C. (2019). Reflective Practice in Physical Therapy: A Scoping Review. Physical Therapy, 99(8), 1056-1068.

Стаття надійшла до редакції 26.02.2020 p. 